\title{
The Concentration of Glycine by Saccharomyces uvarum: Role of the Main Vacuole and Conditions Leading to the Explosive Absorption of the Amino Acid
}

\author{
By KEITH INDGE, ANNE SEASTON AND A. ALAN EDDY \\ Department of Biochemistry, University of Manchester Institute of Science \\ and Technology, Manchester M60 I $Q D$
}

(Received 20 September 1976)

\begin{abstract}
SUMMARY
At $\mathrm{pH}_{4.3}$ in the presence of $2 \%(\mathrm{w} / \mathrm{v})$ glucose and $13 \mathrm{mM}$-glycine, washed cells of Saccharomyces uvarum took up and retained a maximum of about I $\mu \mathrm{mol}$ glycine per mg dry wt. A steady state was reached in which glycine influx was less than Io \% of its initial value, and was largely balanced by the rate of glycine metabolism, efflux being slow. Controlled lysis of the plasmalemma with cytochrome $c$ indicated that little glycine entered the main vacuole. Preliminary starvation of the yeast for $70 \mathrm{~min}$ in the presence of glucose without a nitrogen source led to marked changes: the initial rate of glycine uptake doubled; the amount of glycine retained increased to more than $2 \mu \mathrm{mol} \mathrm{mg}^{-1}$; glycine entered the vacuoles causing them to swell; and many of the cells swelled and burst. The observations indicated that the general aminoacid permease concentrated glycine by a factor of about $5 \times 10^{4}$ at the plasmalemma. The amount of glycine taken up was regulated by both osmotic factors and access to the vacuole.
\end{abstract}

\section{INTRODUCTION}

Although there is now a considerable body of knowledge relating to the general nature of the permeases (Grenson, Hou \& Crabeel, 1970; Kuznar, Schwencke \& MagañaSchwencke, 1973) and to the energetics (Eddy \& Nowacki, 1971; Seaston, Inkson \& Eddy, 1973; Cockburn, Earnshaw \& Eddy, 1975; Seaston, Carr \& Eddy, 1976) of amino-acid transport in yeast, the relation between amino-acid absorption and the existing cellular content of free amino acids is poorly understood, as are the factors governing the amount of amino acid a given yeast preparation absorbs. In the present work we studied the amount of glycine that was absorbed when washed cell suspensions of the yeast Saccharomyces uvarum, in buffered solutions of glucose, were given a relatively large amount of the amino acid. Glycine is degraded only slowly by this yeast (Eddy et al., 1970a) and large cellular pools accumulated. The main aspects examined were: (i) whether the amino-acid pumps were located in the plasmalemma or in the tonoplast (Indge, 1968; Wiemken \& Dürr, 1974; Boller, Dürr \& Wiemken, 1975); (ii) the swelling of the cells during the uptake of amino acids; and (iii) the general relationship between the rate of influx of glycine and its very low natural rate of efflux (Kotyk, Ponec \& Ríhová, 1971; Seaston et al., 1976).

A procedure is described which resulted in an apparent relaxation or abolition of the usual controls on glycine transport by the yeast and which led to the accumulation of so much glycine that some of the cells burst. Study of this system has thrown new light on the factors controlling the amount of glycine absorbed. 


\section{METHODS}

Organism and culture conditions. Saccharomyces uvarum NCYC74 was maintained in a complex nutrient medium and cultivated in a defined mineral salts solution containing $2 \%(\mathrm{w} / \mathrm{v})$ glucose and $2 \%(\mathrm{w} / \mathrm{v})\left(\mathrm{NH}_{4}\right)_{2} \mathrm{SO}_{4}$ (Eddy et al., $\left.1970 \mathrm{a}\right)$. The cultures $(500 \mathrm{ml})$ were shaken in Roux flasks (I 1 capacity) at $25^{\circ} \mathrm{C}$ and harvested in the exponential phase of growth to give about $200 \mathrm{mg}$ dry wt yeast. This was washed with water $(3 \times 50 \mathrm{ml})$ and stored at $4{ }^{\circ} \mathrm{C}$ for up to $30 \mathrm{~h}$.

Glycine transport. The influx and efflux of $\left[\mathrm{I}^{14} \mathrm{C}\right]$ glycine were studied as in our previous work (Eddy et al., 1970 $a$; Seaston et al., 1976). [1-14 C]Glycine was obtained from The Radiochemical Centre, Amersham, and from Schwarz Bio-Research, Orangeburg, New York, U.S.A. The standard assay medium contained $0.02 \mathrm{M}-\mathrm{KCl}, 2 \%(\mathrm{w} / \mathrm{v})$ glucose and $0.02 \mathrm{M}-$ citric acid adjusted to $\mathrm{pH} 4.3$ with Tris. The yeast concentration was usually $4 \mathrm{mg}$ dry wt $\mathrm{ml}^{-1}$, although concentrations as low as $0.01 \mathrm{mg} \mathrm{dry} \mathrm{wt} \mathrm{ml}^{-1}$ were used in some experiments. Starved yeast was prepared by incubating the yeast at $30^{\circ} \mathrm{C}$ in the standard assay medium for $70 \mathrm{~min}$.

The intracellular water space ( \pm S.E.M.) of the washed yeast was $3 \cdot 12 \pm 0 \cdot 16(6) \mu 1 \mathrm{mg}^{-1}$ (dry wt). This was determined from measurements of the wet weight of packed cell pellets of the yeast (approx. $50 \mathrm{mg}$ dry wt), and of the extracellular water accessible to $\left.{ }^{14} \mathrm{C}\right]$ inulin. When the yeast was centrifuged for $10 \mathrm{~min}$ at $2000 \mathrm{~g}$ in polyallomer centrifuge tubes (Beckman Instruments, Glenrothes, Scotland), the extracellular water was reproducibly about $40 \%$ of the total water.

Differential extraction of the yeast. Cytochrome $c$ destroys the yeast cytoplasmic membrane under conditions where the vacuole appears to survive, if the osmotic pressure of the solution surrounding the yeast cells is raised to about I osmolar. The vacuolar contents can then be released by lowering the osmotic pressure (Schlenk, Dainko \& Svihla, 1970; Wiemken \& Nurse, 1973). In practice the yeast was first washed with I.0 M-mannitol solution. The washed cells $\left(0.9\right.$ to $\mathrm{I} \cdot 0 \mathrm{mg}^{\circ}$ dry wt $\left.\mathrm{ml}^{-1}\right), \mathrm{I} \cdot 0 \mathrm{M}$-mannitol and cytochrome $c(100 \mu \mathrm{g}$ $\mathrm{ml}^{-1}$ ) were then stirred together at $30^{\circ} \mathrm{C}$. Because lysis of the yeast tended to increase the $\mathrm{pH}$, a pH-stat (Radiometer model SBR2/SBUI/TTTII/PHM 25, Copenhagen, Denmark) was used to control and record the additions of either $0.0 \mathrm{I} \mathrm{M}-\mathrm{HCl}$, or of $0.0 \mathrm{I} \mathrm{M}$-acetic acid to maintain the $\mathrm{pH}$ at a constant value. The titration was normally complete within $10 \mathrm{~min}$ at $\mathrm{pH}$, the standard value eventually selected (see Fig. 4 and Results). One portion ( $4 \mathrm{ml}$ ) of the yeast suspension was then centrifuged to give the supernatant phase (A), assumed to contain the cytoplasmic constituents of the yeast, and the cell residues. These cell residues were shocked osmotically at $30^{\circ} \mathrm{C}$ by the addition of water ( $\mathrm{r} \mathrm{ml} \mathrm{per} \mathrm{mg} \mathrm{yeast).} \mathrm{After} 4 \mathrm{~min}$ the cell debris was removed by centrifugation. The supernatant solution obtained (B) was assumed to contain the vacuolar contents. To determine the total amount of ${ }^{14} \mathrm{C}$ present, a further portion ( $4 \mathrm{ml}$ ) of the yeast suspension containing cytochrome $c$ was kept at $100^{\circ} \mathrm{C}$ for $10 \mathrm{~min}$. The cell debris was separated from the supernatant solution (C) by centrifugation. The ${ }^{14} \mathrm{C}$ contents of supernatants $\mathrm{A}, \mathrm{B}$ and $\mathrm{C}$ were assayed.

Cytochrome $c$ from horse heart (type III; Sigma) was used.

\section{RESULTS}

Time course of glycine uptake in the presence of glucose

The washed yeast cells were suspended at $30{ }^{\circ} \mathrm{C}$ in $0.02 \mathrm{M}$-citric acid adjusted to $\mathrm{pH} 4 \cdot 3$ with Tris and containing $0.02 \mathrm{M}-\mathrm{KCl}$ and $2 \%(\mathrm{w} / \mathrm{v})$ glucose. After $5 \mathrm{~min}\left[\mathrm{I}^{14} \mathrm{C}\right]$ glycine 


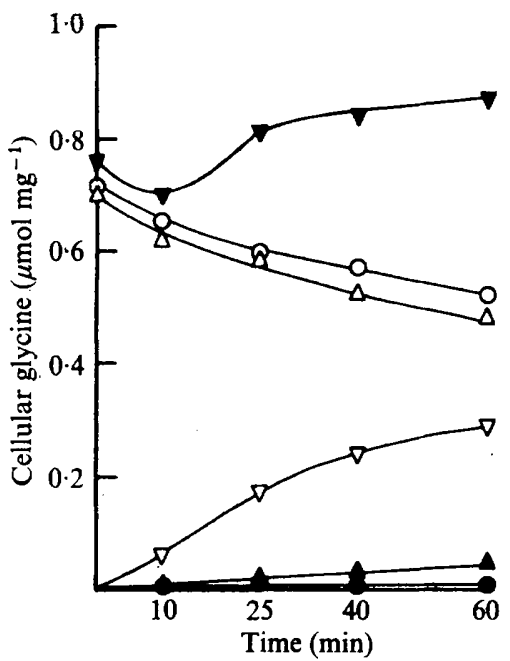

Fig. I

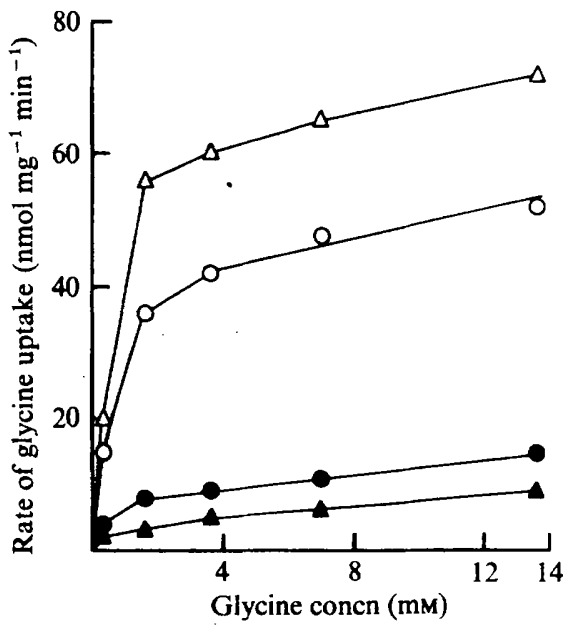

Fig. 2

Fig. I. Glycine fluxes in the steady state. The yeast was incubated in the standard medium with $\left[{ }^{14} \mathrm{C}\right] \mathrm{glycine}(13 \mathrm{~mm})$. After $60 \mathrm{~min}$, when net uptake hadalmost ceased, the yeast was washed and then suspended in fresh medium without glycine $(O, O)$, with $13 \mathrm{~mm}-\left[{ }^{12} \mathrm{C}\right]$ glycine $(\Delta, \Delta)$ or with $13 \mathrm{~mm}-\left[{ }^{14} \mathrm{Clg}\right]$ ycine $(\nabla)$. Radioactivity in the yeast $(\nabla, O, \Delta)$ and in the medium $(0, \Delta)$ is expressed as $\mu \mathrm{mol}$ glycine (mg yeast) ${ }^{-1}$. Glycine uptake $(\nabla)$ by yeast incubated initially with 13 mm$\left[{ }^{12} \mathrm{C}\right] \mathrm{glycine}$ and transferred to $13 \mathrm{mM}-\left[{ }^{14} \mathrm{C}\right] \mathrm{glycine}$.

Fig. 2. Concentration dependence of the initial velocity of glycine uptake and inhibition of uptake by intracellular glycine. The yeast was incubated in the standard medium for $30(O)$ or $60(\triangle) \mathrm{min}$, then washed and suspended in fresh medium. $\left[{ }^{14} \mathrm{C}\right]$ Glycine was added to samples, to the final concentrations shown, and uptake was measured over I min. The two lower curves show parallel experiments in which the yeast was incubated initially for $30(0)$ or $60(\Delta) \mathrm{min}$ with $13 \mathrm{mM}-\left[{ }^{12} \mathrm{C}\right]$ glycine.

$\left(0.02 \mathrm{mCi} \mathrm{mmol}^{-1}\right)$ was added to give a $13 \mathrm{~mm}$ solution. There followed a gradual increase in the cellular content of glycine which reached a steady value after $40 \mathrm{~min}$. The initial rate of glycine uptake was $37 \pm 7$ (9) S.D. $\mathrm{nmol} \mathrm{mg}^{-1} \mathrm{~min}^{-1}$ and in the steady state the yeast contained $0.89 \pm 0.10$ (9) S.D. $\mu \mathrm{mol}$ glycine $\mathrm{mg}^{-1}$, corresponding to about a $0.28 \mathrm{M}$ solution in the cellular water.

We had established previously that the ${ }^{14} \mathrm{C}$ extracted from the yeast by hot water provided a reliable measure of cellular glycine (Eddy et al., 1970a). These observations were extended in the present work by showing that about $95 \%$ of the cellular ${ }^{14} \mathrm{C}$ was associated with free glycine and that there was a close correspondence between radiochemical and colorimetric assays of uptake. In one experiment the yeast initially contained ninhydrin-reactive materia] equivalent to $0.3 \mathrm{I} \mu \mathrm{mol}$ glycine per $\mathrm{mg}$ dry wt cells. Using procedures which are described later, the yeast was allowed to accumulate glycine to levels of $\mathrm{I} \cdot \mathrm{I}, \mathrm{I} \cdot 39$ and $\mathrm{I} \cdot 59 \mu \mathrm{mol} \mathrm{mg}^{-1}$ as determined radiochemically. The corresponding ninhydrin assays were $I \cdot 48, I \cdot 80$ and $\mathrm{r} \cdot 94 \mu \mathrm{mol} \mathrm{mg} \mathrm{m}^{-1}$.

\section{Control of glycine uptake}

The results of experiments designed to elucidate the processes operating in the steady state are shown in Figs I and 2. During the steady state, when the cellular ${ }^{{ }^{14}} \mathrm{C}$ content and hence the glycine content were approximately constant, there was an appreciable turnover of glycine, only a relatively slow efflux of glycine to the medium and a negligible incorporation of ${ }^{14} \mathrm{C}$ into the hot water-insoluble fraction of the yeast. Figure 2 shows that the net rate of 


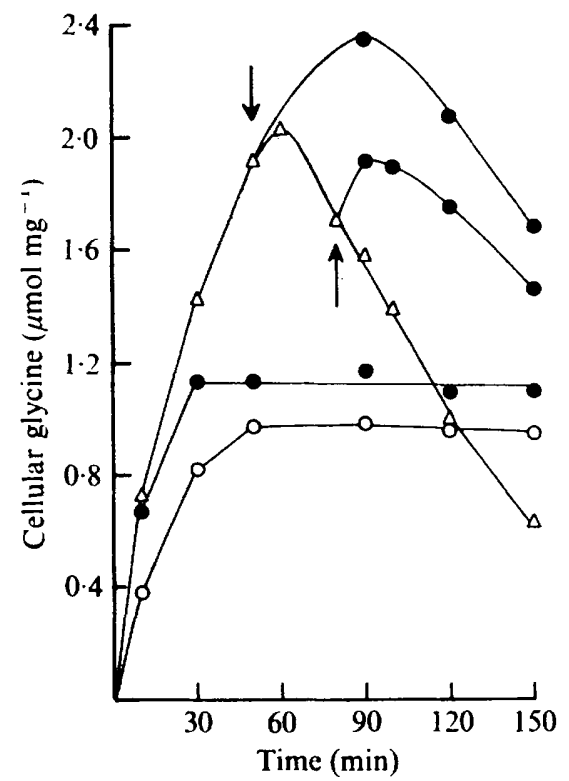

Fig. 3. Glycine uptake leading to lysis of starved yeast. Progress curves of glycine uptake by starved $(\Delta)$ and unstarved $(O)$ yeast. Also shown $(O)$ are the effects on glycine uptake by the starved yeast of adding $\mathrm{KCl}$, to a final concentration of $0.2 \mathrm{M}$, at time zero, $50 \mathrm{~min}(\downarrow)$ or $80 \mathrm{~min}(\uparrow)$.

glycine transport in the steady state was much smaller than the initial rate of glycine uptake. Glycine uptake by this yeast strain can be resolved into two kinetic components having $K_{\mathrm{m}}$ values of $64 \mu \mathrm{m}$ and $2.8 \mathrm{~mm}$ (Eddy et al., 1970a). Figure 2 shows that when the yeast had already accumulated glycine for $60 \mathrm{~min}$, the former kinetic component was virtually abolished. These results and similar observations by other workers (Kotyk et al., 1971 ; Crabeel \& Grenson, 1970) illustrate an important device for regulating transport in yeast, namely the substrate-induced inhibition or transinhibition (Hunter \& Segel, 1973) of carrier function, the mechanism of which appears to be complex. Possible explanations of the slow efflux of amino acids from yeast are discussed by Seaston et al. (1976).

In the steady state, the residual glycine influx from 13 mM-glycine was not balanced by efflux as would be the case if accumulation were regulated by a pump-leak mechanism (Fig. I). Earlier work had shown a conversion of $\left[\mathrm{I}^{14} \mathrm{C}\right] g$ lycine into ${ }^{14} \mathrm{CO}_{2}$ (Eddy et al., 1970 a). Thus the respective rates of glycine breakdown and of the essentially unidirectional transport of the amino acid appeared to determine the intracellular concentration of glycine in the steady state. Glycine breakdown, measured as the net loss of ${ }^{14} \mathrm{C}$ from the system, was $0.13 \pm 0.01$ (4) S.D. $\mu \mathrm{mol} \mathrm{mg}^{-1} \mathrm{~h}^{-1}$ and was independent of the average glycine content of the

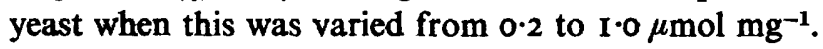

\section{Uncontrolled glycine uptake}

Incubating the yeast with glucose for 60 min increased the subsequent rate of glycine transport (Fig. 2). Although a further increase in rate, of the order of 10 to $15 \%$, took place if the yeast was starved for $2 \mathrm{~h}$, a standard starvation period of $70 \mathrm{~min}$ was adopted.

The treatment with glucose (starvation) resulted in a number of striking changes in the properties of the system. The rate of glycine uptake from a $13 \mathrm{~mm}$ solution was approximately doubled to $84 \pm 7$ (I I) S.D. $\mathrm{nmol} \mathrm{mg}^{-1} \mathrm{~min}^{-1}$. The amount of glycine taken up 
Table I. Volumes of vacuolar and cytoplasmic compartments as influenced by glycine or lysine uptake

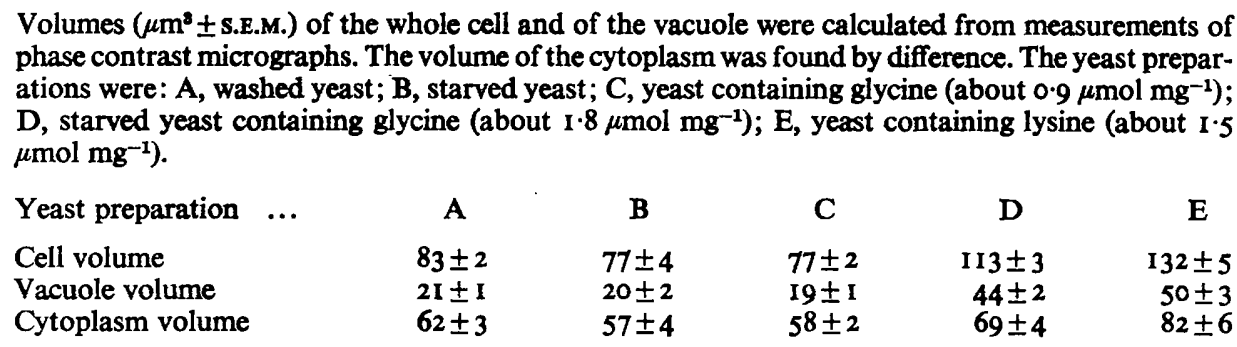

increased to $2 \cdot 00 \pm 0 \cdot 18$ (8) S.D. $\mu \mathrm{mol} \mathrm{mg}^{-1}$. As shown in Fig. 3, a phase of net glycine loss from the yeast appeared in the time course of the experiments. After 50 to $60 \mathrm{~min}$ the yeast cells became grossly swollen and they flocculated. Observations with the light microscope revealed that the vacuole had expanded until it appeared to fill the yeast cell, and that a large fraction of the yeast had lysed.

We concluded that lysis of the yeast caused by, or greatly stimulated by, the large amounts of glycine accumulated gave rise to the abnormal time course of uptake seen in these experiments. Apparently the mechanism which normally served to regulate transport had failed to work effectively in the starved yeast.

Raising the osmotic pressure of the medium during the lysis phase by adding $\mathrm{KCl}, \mathrm{NaCl}$ or mannitol (Fig. 3) showed that, despite the presence of a large amount of glycine in the yeast, the rate of glycine transport was not greatly diminished. Furthermore, the yeast preparations exposed to glucose and then loaded with $\left[{ }^{12} \mathrm{C}\right]$ glycine for 50 to $60 \mathrm{~min}$, subsequently transported $\left[{ }^{4} \mathrm{C}\right]$ glycine at apparent rates of 30 to $40 \mathrm{nmol} \mathrm{mg}^{-1} \mathrm{~min}^{-1}$. Lysis would clearly result in an underestimation of the actual transport rate in these circumstances.

Starved yeast labelled with $\left.{ }^{14} \mathrm{C}\right]$ glycine $\left(\mathrm{I} \cdot 0\right.$ to $\left.\mathrm{I} \cdot 3 \mu \mathrm{mol} \mathrm{mg}^{-1}\right)$ lost ${ }^{24} \mathrm{C}$, presumably as glycine, to glycine-free media at rates ranging from 0.7 to $\mathrm{I} \cdot \mathrm{I} \mathrm{nmol} \mathrm{mg}^{-1} \mathrm{~min}^{-1}$ (three experiments). Glycine metabolism, estimated as the net ${ }^{14} \mathrm{C}$ loss from the system, was about

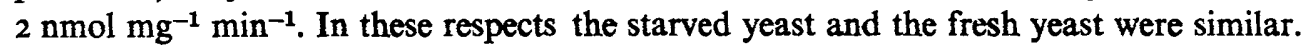

\section{Swelling of the yeast}

The swelling of the yeast cells which accompanied the accumulation of these large amounts of glycine was apparent in phase-contrast micrographs. Between 70 and 150 cells were measured using a travelling micrometer and the volumes of the whole cell and vacuole, corresponding to each set of experimental conditions, were calculated. The results (Table I) demonstrate that an increase in cell volume, associated with the uptake of glycine, occurred only in the starved yeast. The increases in volume of the whole cell, vacuole and, by difference, the cytoplasm were respectively, about $50 \%, 130 \%$ and $20 \%$. We estimate that the glycine concentration in the cellular water of the starved yeast was at least $0.45 \mathrm{M}$ when the cellular glycine content was $2 \mu \mathrm{mol} \mathrm{mg}^{-1}$.

\section{Other amino acids}

The uptake of other amino acids ( $13 \mathrm{mM}$ ) by the starved yeast was measured with the ninhydrin reagent and swelling or lysis was assessed by microscopic examination. The amino acids tested, and in parentheses the amounts $\left(\mu \mathrm{mol} \mathrm{mg}^{-1}\right)$ taken up during $60 \mathrm{~min}$, were L-valine (0.9I), L-leucine ( $\mathrm{I} \cdot 04)$, L-alanine ( $1 \cdot 73)$, L-methionine ( $1 \cdot 02)$, L-phenylalanine $(0.58)$, 
Table 2. Effects of osmotic pressure and ammonium ions on glycine transport

Additions were made to the standard assay medium as indicated, and the initial rate of glycine uptake $\left(V_{1}, \mathrm{nmol} \mathrm{mg}^{-1} \mathrm{~min}^{-1}\right)$ and the amount of glycine absorbed $\left(\mu \mathrm{mol} \mathrm{mg} \mathrm{m}^{-1}\right)$ by starved and unstarved yeast were determined. In experiments in which $\mathrm{NH}_{4} \mathrm{Cl}$ was present, this was added to the yeast suspension $10 \mathrm{~min}$ before glycine was added.

\begin{tabular}{|c|c|c|c|c|}
\hline \multirow[b]{2}{*}{ Addition } & \multicolumn{2}{|c|}{ Starved yeast } & \multicolumn{2}{|c|}{ Unstarved yeast } \\
\hline & $V_{1}$ & Glycine absorbed & $V_{\mathbf{i}}$ & Glycine absorbed \\
\hline None & 87 & $2 \cdot 05$ & 44 & 0.96 \\
\hline $\mathbf{K C l}, \mathbf{O} \cdot \mathbf{I} \mathbf{M}$ & 85 & $I \cdot 74$ & 一 & - \\
\hline $\mathrm{KCl}, 0.2 \mathrm{M}$ & 80 & $1 \cdot 23$ & 29 & 0.96 \\
\hline $\mathrm{KCl}, 0.3 \mathrm{M}$ & 67 & 1.09 & - & - \\
\hline $\mathrm{KCl}, 0.4 \mathrm{M}$ & 57 & $1 \cdot 03$ & 一 & - \\
\hline None & 81 & $2 \cdot 30$ & - & - \\
\hline $\mathrm{KCl}, 0.2 \mathrm{M}$ & 75 & $1 \cdot 35$ & 一 & - \\
\hline $\mathrm{NaCl}, 0.2 \mathrm{M}$ & 73 & $I \cdot 20$ & - & - \\
\hline Mannitol, $0.4 \mathrm{M}$ & 72 & $I \cdot 3 I$ & 一 & - \\
\hline None & 76 & $2 \cdot 05$ & $4 I$ & 0.74 \\
\hline $\mathrm{NH}_{4} \mathrm{Cl}, 2 \mathrm{mM}$ & 56 & $1 \cdot 28$ & 23 & 0.68 \\
\hline $\mathrm{NH}_{4} \mathrm{Cl}, 10 \mathrm{~mm}$ & 54 & $1 \cdot 18$ & 22 & 0.32 \\
\hline
\end{tabular}

glycine (2.53), L-histidine, L-tryptophan and L-aspartate. Apart from glycine, only alanine caused clumping, swelling and lysis of the yeast but the effects were less marked than with glycine.

L-Lysine was exceptional. Like glycine, the rate of lysine transport from a $13 \mathrm{~mm}$ solution

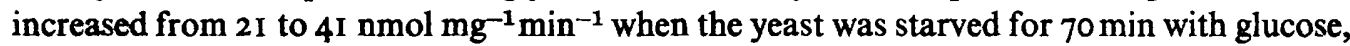
but the amount of lysine accumulated during $2 \mathrm{~h}$ increased only moderately, from $\mathrm{I} \cdot 49$ to

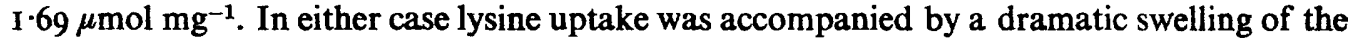
cell $(71 \%)$ and of the vacuole ( $150 \%$ ) (Table I) but the yeast did not appear to lyse as readily as when swollen with glycine. Preliminary work indicated that L-arginine resembled lysine in that pronounced vacuolar swelling accompanied its absorption even though the yeast had not been starved in glucose.

\section{Other factors influencing uncontrolled transport}

Transport-induced lysis was prevented by increasing the osmotic pressure of the medium either before adding glycine or during the first 10 min of uptake. Later additions of $\mathrm{NaCl}, \mathrm{KCl}$ or mannitol delayed, but did not prevent, lysis (Fig. 3). The illustrative data in Table 2 show that a high osmotic pressure lowered the amount rather than the rate of glycine uptake. Treating the yeast with $0.3 \mathrm{M} \mathrm{KCl}$ and glucose for $70 \mathrm{~min}$, before tests with glycine under the usual experimental conditions, did not prevent uncontrolled transport. In those experiments where an osmoticum had prevented lysis, the rate of glycine transport in the steady state

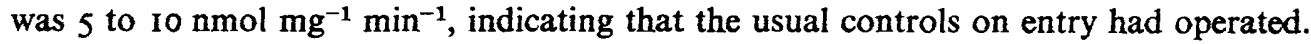

Ammonium ions also inhibited transport of glycine (Table 2) and the associated lysis of the starved yeast. The situation was complex since, to be effective, $\mathrm{NH}_{4} \mathrm{Cl}$ had to be added at least $10 \mathrm{~min}$ before the glycine.

Uncontrolled transport of glycine resulted only when the yeast was starved in glucose solutions. Starvation for $70 \mathrm{~min}$ without glucose lowered the rate of uptake of glycine from

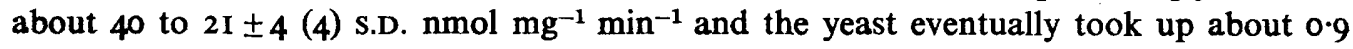

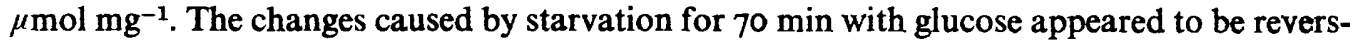
ible. When such preparations were incubated without glucose for a further $30 \mathrm{~min}$, the 
Table 3. Concentration of glycine by starved yeast

\begin{tabular}{|c|c|c|c|c|c|}
\hline $\begin{array}{l}\text { Yeast concn } \\
\left(\mathrm{mg} \mathrm{ml}^{-1}\right)\end{array}$ & $\begin{array}{c}\text { Initial glycine } \\
\text { concn (mM) }\end{array}$ & Time (min) & $\begin{array}{c}\text { Glycine concn } \\
\text { in medium } \\
(\mu \mathrm{M})\end{array}$ & $\begin{array}{l}\text { Glycine concn } \\
\text { in yeast } \\
(\mu \text { mol mg-1 })\end{array}$ & Concn ratio \\
\hline 0.10 & 0.133 & 60 & II'O & $I \cdot 12$ & 32600 \\
\hline 0.10 & 0.133 & 50 & $7 \cdot 6$ & 1.03 & 43400 \\
\hline 0.10 & 0.133 & 65 & 6.5 & 0.97 & 47800 \\
\hline 0.04 & 0.053 & 60 & 8.0 & 0.95 & 38000 \\
\hline 0.04 & 0.053 & 45 & $9 \cdot 9$ & 0.69 & 22300 \\
\hline 0.04 & 0.039 & 60 & $4 \cdot 3$ & 0.46 & 34300 \\
\hline 0.04 & 0.026 & 60 & $2 \cdot 4$ & 0.28 & 37400 \\
\hline
\end{tabular}

subsequent transport of glycine was relatively slow ( $50 \mathrm{nmol} \mathrm{mg} \mathrm{min}^{-1}$ ), net uptake ceased at about I I I $\mu \mathrm{mol} \mathrm{mg}^{-1}$ and no lysis occurred. Uncontrolled transport did not result if the yeast was loaded with glycine $\left(0.7 \mu \mathrm{mol} \mathrm{mg}^{-1}\right)$, and then starved in glucose before being exposed again to glycine.

\section{Cellular content of $\mathrm{K}^{+}$}

Applying the standard starvation procedure with glucose to four preparations of yeast led to a decrease in the pool of ninhydrin-reactive compounds from $0.42 \pm 0.06$ to $0.28 \pm 0.03$ S.D.

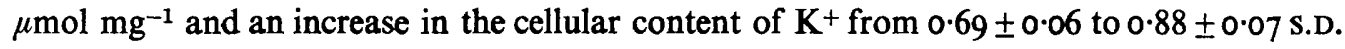

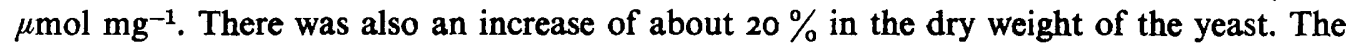
absorption of glycine from a $13 \mathrm{mM}$ solution for $60 \mathrm{~min}$ lowered the $\mathrm{K}^{+}$content of the starved yeast from about $0.9 \mu \mathrm{mol} \mathrm{mg}^{-1}$ in the controls to about $0.6 \mu \mathrm{mol} \mathrm{mg}^{-1}$. The corresponding values at $120 \mathrm{~min}$ were 0.9 and $0.4 \mu \mathrm{mol} \mathrm{mg}^{-1}$. The unstarved yeast similarly lost $0.4 \mu \mathrm{mol} \mathrm{K}+$ during $\mathrm{I} 20 \mathrm{~min}$ in the presence of glycine. Although they followed the same time course, the net loss of $\mathrm{K}^{+}$was not stoicheiometric with respect to the amount of glycine absorbed.

\section{Concentration ratio}

The apparent loss in the starved yeast of the usual control exerted by cellular glycine on glycine influx provided an opportunity to investigate the extent to which the yeast concentrated glycine. The assays were complicated by the presence of impurities in the $\left[\mathrm{I}^{-14} \mathrm{C}\right] \mathrm{glycine}$ which were not concentrated by the yeast, and therefore caused the conoentration ratio to be underestimated. The problem was recognized initially from the observation that in tests where substrate depletion of the medium occurred the fraction of the total radioactivity remaining was constant and was independent of the amount of carrier glycine added. Impurity levels ranging from $3 \cdot I$ to $14 \cdot 2 \%$ were found by chromatography of different batches of $\left[{ }^{14} \mathrm{C}\right]$ glycine. The $\left[{ }^{1-}{ }^{14} \mathrm{C}\right]$ glycine used in the experiments shown in Table 3 contained not more than $2 \%$ radioactive impurities according to the supplier (The Radiochemical Centre, Amersham) and $3 \cdot r \%$ impurities by our own assays.

Errors arising from the impurities can be minimized by working with dilute yeast suspensions, so.that the residual $\left[{ }^{14} \mathrm{C}\right]$ glycine counts in the medium at least equal the estimated count of the impurities. Table 3 shows a selection of the experimental data, the largest concentration ratio observed being about $5 \times 10^{4}$. While the kinetic parameters of the system did not permit the use of yeast concentrations below $0.04 \mathrm{mg} \mathrm{ml}^{-1}$, and there is some uncertainty 

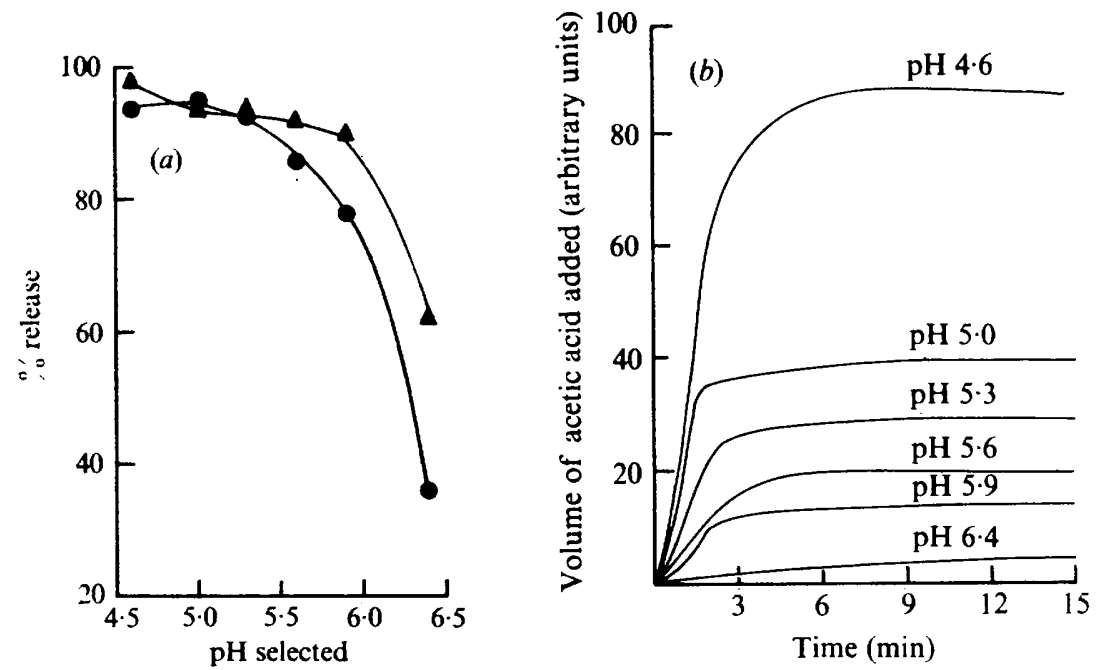

Fig. 4. Effect of $\mathrm{pH}$ on the lysis of the yeast by cytochrome $c$. The yeast contained $\left[{ }^{14} \mathrm{Clglycine}\right.$ $\left(0.80 \mu \mathrm{mol} \mathrm{mg}^{-1}\right)$ and $\mathrm{K}^{+}\left(0.93 \mu \mathrm{mol} \mathrm{mg}^{-1}\right)$. It was suspended $\left(0.975 \mathrm{mg} \mathrm{m}^{-1}\right)$ in $20 \mathrm{ml}$ water at $30^{\circ} \mathrm{C}$. The $\mathrm{pH}$ was adjusted as required with $0.0 \mathrm{I} \mathrm{M}$-acetic acid on a pH-stat. Cytochrome $c\left(100 \mu \mathrm{g} \mathrm{ml}^{-1}\right)$ was added at time zero. (a) Percentage losses of $\mathrm{K}^{+}(\boldsymbol{\Delta})$ and ${ }^{14} \mathrm{Clglycine}(O)$ from the yeast after $10 \mathrm{~min}$, indicating how the extent of lysis varied with the pH selected. (b) Volume of $0.01 \mathrm{M}$-acetic acid added to keep the $\mathrm{pH}$ constant at the value selected, shown in arbitrary units as a function of time. At pH 5 about $0.4 \mu \mathrm{mol} \mathrm{OH}^{-}$was released. Because of incomplete dissociation of the acetic acid, the volume of acid added is not a direct measure of the extent of lysis.

regarding the level of impurities in the $\left[{ }^{14} \mathrm{C}\right]$ glycine, is seems likely that the maximum concentration ratio achieved by the starved yeast was between $5 \times 10^{4}$ and $10^{5}$.

\section{Intracellular localization of amino acids}

The foregoing observations implicated the cell vacuole as one site of glycine accumulation in the starved preparations. A different approach to the problem was to extract the cellular amino acids selectively with cytochrome $c$ (see Methods). The procedure of stepwise extraction developed by Schlenk et al. (1970) depends on the selective disruption of the plasmalemma. In isotonic solutions the vacuole appears to be preserved and its contents can be liberated subsequently by lowering the tonicity of the solution.

In preliminary experiments with yeast suspended in water, 20 to $30 \%$ of the cells were apparently unaffected by cytochrome $c$ (cf. Yphantis, Dainko \& Schlenk, 1967; Wiemken \& Nurse, 1973) even when the initial pH was adjusted to $5^{\circ} 0$ with acetic acid (Svihla, Dainko \& Schlenk, 1969). A marked increase in the efficiency of extraction was obtained by maintaining the $\mathrm{pH}$ of the reaction at a constant value between 5.0 and 5.5 on a pH-stat (Fig. 4). The conditions during the osmotic shock treatment were also examined. It is interesting that yeast which had not been treated with cytochrome $c$ became sensitive to an osmotic shock when the cell preparation was incubated for $10 \mathrm{~min}$ in I M-mannitol at $30^{\circ} \mathrm{C}$. Sensitization did not occur at $0^{\circ} \mathrm{C}$. This rather surprising temperature dependence of the hyperosmotic phase of the process, which may accordingly involve enzyme action, does not appear to have been noted previously (Patching \& Rose, 197I ; Schwencke, Farfas \& Rojas, 197I). The subsequent lysis of the yeast by the osmotic shock was influenced by the temperature and composition of the shock medium. $\mathrm{KCl}, \mathrm{MgCl}_{2}, \mathrm{KH}_{2} \mathrm{PO}_{4}$ or Tris/ $\mathrm{HCl}$ increased lysis, as did prior treatment of the yeast in mannitol plus EDTA. Illustrative data are given in 
Table 4. Factors influencing the spontaneous release of ${ }^{14} \mathrm{C}$ from the yeast during an osmotic shock treatment

\begin{tabular}{|c|c|c|c|c|}
\hline \multirow[b]{2}{*}{ Conditions of osmotic shock } & \multicolumn{4}{|c|}{ Pretreatment of yeast } \\
\hline & $0^{\circ} \mathrm{C}$ & $30^{\circ} \mathrm{C}$ & EDTA, $0^{\circ} \mathrm{C}$ & EDTA, $30^{\circ} \mathrm{C}$ \\
\hline $\begin{array}{l}\mathrm{KH}_{2} \mathrm{PO}_{4}(0.05 \mathrm{M}), 0{ }^{\circ} \mathrm{C} \\
\mathrm{KH}_{2} \mathrm{PO}_{4}(0.05 \mathrm{M}), 30^{\circ} \mathrm{C}\end{array}$ & $\begin{array}{l}2 \cdot 8 \\
1 \cdot 8\end{array}$ & $\begin{array}{l}78 \cdot 5 \\
68 \cdot 1\end{array}$ & & \\
\hline Water, $0{ }^{\circ} \mathrm{C}$ & $1 \cdot 0$ & $3 I \cdot 9$ & $7 \cdot 9$ & $70 \cdot 6$ \\
\hline $\begin{array}{l}\mathrm{KCl}(0.05 \mathrm{M}), 30^{\circ} \mathrm{C} \\
\mathrm{KCl}(0.01 \mathrm{M}), 30^{\circ} \mathrm{C}\end{array}$ & 0.7 & $\begin{array}{l}10 \cdot 1 \\
74 \cdot 8 \\
37 \cdot 3\end{array}$ & 79 & \\
\hline
\end{tabular}

Table 4. The shock-induced release of solutes was accompanied by an equivalent decrease in the rate of glycine accumulation by the yeast.

These observations established conditions (Methods) which resulted in about $95 \%$ of the endogenous amino acids, $\mathrm{K}^{+}$or accumulated $\left[{ }^{4} \mathrm{C}\right] \mathrm{glycine}$ each being released from the yeast cells. Extending the experiments to include yeast suspensions in mannitol, it was found that the presence of I M-mannitol lowered by 10 to $15 \%$ the amounts of the endogenous amino acids released by the action of cytochrome $c$. This minor fraction of the cellular amino acids, which is assumed to be vacuolar in origin, was subsequently extracted by the osmotic shock procedure. Likewise, when the yeast contained less than $0.9 \mu \mathrm{mol}\left[{ }^{14} \mathrm{C}\right]$ glycine $\mathrm{mg}^{-1}$, only about $15 \%$ of the radioactivity was retained by the yeast after the treatment with cytochrome $c$ and released by the subsequent osmotic shock (Fig. 5). However, up to $45 \%$ of the radioactivity behaved in this fashion when the yeast contained $\mathrm{I} \cdot 0$ to $\mathrm{I} \cdot 5 \mu \mathrm{mol}\left[{ }^{14} \mathrm{C}\right]$ glycine $\mathrm{mg}^{-1}$ (Fig. 5). Control extractions of the yeast in the absence of mannitol reproducibly released 90 to $98 \%$ of the cellular amino acids. The cytoplasmic and vacuolar fractions together accounted for 96 to $103 \%$ of the total amino acids of the yeast, which suggested that when they were suspended in $\mathrm{I} \cdot 0 \mathrm{M}$-mannitol a similar proportion of the yeast cells were damaged by cytochrome $c$. Microscopic examination of the cytochrome $c$-treated yeast cells showed no evidence of vacuolar lysis prior to their being shocked in water. Further support for the supposition that a differential extraction was achieved came from the observation that, in experiments where up to $45 \%$ of the glycine was retained by the yeast, 92 to $96 \%$ of the cellular $\mathrm{K}^{+}$was released to the medium (Fig. 5).

These results were quite unlike those reported by Wiemken \& Nurse (1973) for another species of yeast, even though we varied the conditions of the extractions widely by changing the $\mathrm{pH}$, temperature, concentration of cytochrome $c$ and reaction time in an effort to reproduce their observations. Some extractions were carried out at $0^{\circ} \mathrm{C}$, since a low temperature is a feature of the procedure used by Wiemken \& Nurse (1973). Cytochrome $c$ (100 $\mu \mathrm{g} \mathrm{ml}^{-1}$ ) had no detectable effect on the yeast $\left(\mathrm{I} \mathrm{mg} \mathrm{ml}^{-1}\right)$ during $10 \mathrm{~min}$ at $0^{\circ} \mathrm{C}$ (cf. Yphantis et al., 1967) although larger concentrations ( 500 to $1000 \mu \mathrm{g} \mathrm{ml}^{-1}$ ) did result in lysis. It is evident that the optimum conditions for lysis by cytochrome $c$ may vary with the yeast species.

Similar experiments were done with the yeast which had accumulated lysine. The results were quantitatively like those with the yeast containing glycine, with amounts of lysine up to

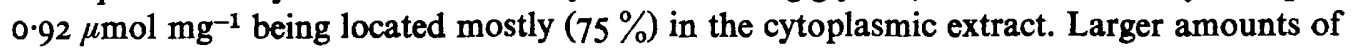




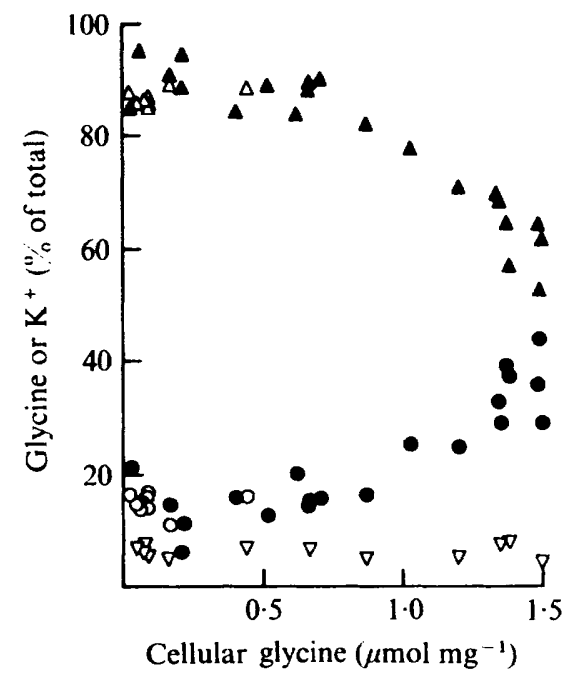

Fig. 5. Distribution of glycine between the cytoplasmic and the vacuolar fractions. The percentage of the total $\left[{ }^{14} \mathrm{C}\right.$ lglycine in the cytoplasmic $(\triangle, \Delta)$ and the vacuolar $(O, 0)$ extracts of glycineloaded yeast is shown. Extracts were prepared as described in Methods. Experimental points for unstarved and'starved yeast are not distinguished, but the open symbols $(\triangle, O)$ refer to yeast loaded with glycine as in Table 5. The percentage of the total $\mathrm{K}^{+}$in the vacuolar fraction $(\nabla)$ is shown for selected experiments.

\section{Table 5. Subcellular distribution of glycine absorbed with protons at pH 4.5} by yeast preparations depleted of ATP

The yeast was grown with glucose and $\left(\mathrm{NH}_{4}\right)_{2} \mathrm{SO}_{4}$ in three separate cultures and then kept at $30^{\circ} \mathrm{C}$ with $5 \%(w / v)$ glucose for $30 \mathrm{~min}$. The washed cells ( $50 \mathrm{mg}$ dry wt) were suspended at $\mathrm{pH} 4.5$ at $30^{\circ} \mathrm{C}$ with $25 \mu \mathrm{g}$ antimycin and $5 \mathrm{~mm}$-2-deoxyglucose in a final volume of $4 \mathrm{ml}$. After $2 \mathrm{~min}, 0.5 \mu \mathrm{mol}$ $\left[{ }^{14} \mathrm{C}\right.$ lglycine $(0.5 \mu \mathrm{Ci})$ was added. The increase caused by glycine in the rate of proton absorption by the yeast, the number of additional protons absorbed with the glycine during the next 3 min (Seaston et al., 1976), and the distribution of the cellular glycine between the vacuolar and cytosol fractions (Methods) were assayed.

\begin{tabular}{|c|c|c|c|c|}
\hline \multirow[b]{2}{*}{ Expt } & \multirow{2}{*}{ 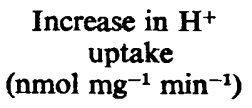 } & \multirow{2}{*}{$\frac{\text { Extra } \mathrm{H}^{+} \text {absorbed }}{\text { Glycine absorbed }}$} & \multicolumn{2}{|c|}{ Percentage of absorbed glycine in: } \\
\hline & & & Cytosol fraction & Vacuolar fraction \\
\hline $\mathbf{I}$ & 12 & I 95 & 86 & I4 \\
\hline 2 & IO & $\mathrm{I} \cdot 9$ & 84 & 16 \\
\hline 3 & 6 & $1 \cdot 75$ & 86 & 14 \\
\hline
\end{tabular}

lysine were distributed increasingly into the vacuole fraction and $44 \%$ of the lysine was recovered in this fraction when the yeast contained $\mathrm{I} \cdot 20 \mu \mathrm{mol} \mathrm{mg}^{-1}$. Yeast which contained large amounts of lysine reacted more slowly with cytochrome $c$ than did the glycine yeast and $20 \%$ of the cells were resistant to attack. For these reasons the experiments were less satisfactory than those with yeast containing glycine.

\section{Glycine accumulated by yeast preparations depleted of ATP}

Preparations of the yeast that had been depleted of ATP in the presence of 2-deoxyglucose and antimycin accumulated up to about $20 \mathrm{nmol}$ glycine per mg dry wt of yeast at $\mathrm{pH} 4.5$, apparently by utilizing the energy inherent in the proton gradient acting across the plasmalemma (Eddy, Backen \& Watson, 1970 b; Eddy \& Nowacki, 1971; Seaston et al., 1976). The 
maximum ratio of the concentrations of cellular and extracellular glycine was probably about $4 \times 10^{4}$ when the extracellular glycine concentration was about $0.1 \mu \mathrm{M}$. It may be fortuitous that similar concentration ratios were observed during energy metabolism (Table 3) since the proton gradient acting across the plasmalemma was not necessarily equal to that acting in the preparations depleted of ATP. Table 5 shows that during lysis with cytochrome $c$ the glycine absorbed with protons under these conditions behaved as though it was located outside the vacuole. Assays with ninhydrin confirmed previous evidence (Eddy et al., $1970 \mathrm{~b}$ ) that the added glycine was not simply exchanging with the endogenous amino-acid pool. Hence we suggest that the proton symport mechanism concentrates glycine at the plasmalemma.

\section{DISCUSSION}

Location of amino-acid pool. Our observations are consistent with previous indications in the literature that the main vacuole contains a significant fraction of the cellular pool of amino acids with distinctive metabolic characteristics (Indge, 1968; Wiemken \& Nurse, 1973; Wiemken \& Dürr, 1974). The vacuolar pool possibly represents a reserve of nitrogen (Matile, Moor \& Robinow, 1969; Brown \& Johnson, 1970; Wiemken \& Dürr, 1974). The fact that the vacuole swells when it absorbs lysine or glycine is striking evidence both that it participates in the transport of these amino acids and that the differential lysis with cytochrome $c$ gives meaningful results. Nevertheless comparison of the results of the present work with those in the literature leads to a complex picture. About 20 to $40 \%$ of the total endogenous pool of soluble amino acids was in the cytosol outside the vacuole of Candida utilis (Wiemken \& Nurse, 1973; Dürr, Boller \& Wiemken, 1975), whereas about $40 \%$ of the relatively large endogenous amino-acid pool [ $\mathrm{I} \cdot 7 \mu \mathrm{mol} \mathrm{N}$ (mg dry wt) $\left.{ }^{-1}\right]$ was in the cytosol fraction derived from disrupted protoplasts of Saccharomyces cerevisiae (Wiemken \& Dürr, 1974). In the present work about $90 \%$ of the smaller endogenous pool $\left(0.4 \mu \mathrm{mol} \mathrm{N} \mathrm{mg}{ }^{-1}\right)$ was located in the non-vacuolar fraction. Taken together, these observations, which involve different yeasts grown in different ways, are inconsistent with the generalization made by Boller et al. (1975), namely that the bulk of the soluble amino acids are located in the main vacuole. Moreover, of the glycine absorbed from the environment, the fraction outside the vacuole varied from about $90 \%$ to $50 \%$ with the duration of the incubation, under conditions where lysine also entered both compartments. Endogenous glutamate, however, tended to be excluded from the vacuole (Wiemken \& Dür, 1974). Hence we suggest that the distribution of a given amino acid between the two compartments varies not only with the nature of the amino acid and its origin but also with the physiological state of the yeast which, in turn, determines the size of the endogenous amino-acid pool (Brown \& Johnson, 1970).

Location of the glycine pump. Boller et al. (1975), believing that the endogenous amino acids were mainly in the vacuole, recently posed the question of whether the amino-acid pumps were located in the vacuolar membrane. We have hitherto supposed that the concentration of amino acids is effected by symport mechanisms situated in the plasmalemma rather than the vacuole (Eddy \& Nowacki, 197I; Seaston, et al., 1973). The coincident absorption of protons with several amino acids (Seaston et al., 1973) is consistent with that view, as are the observations (Tables 3 and 5) which demonstrate that large gradients of glycine concentration formed in circumstances where most of the amino acid was apparently not located in the vacuole. The symport hypothesis is greatly strengthened by the finding that yeast preparations depleted of ATP utilize the proton gradient to establish ratios of glycine concentrations of similar magnitude to those shown in Table 3 (Seaston et al., 1976). 
We observed a net efflux of $\mathrm{K}^{+}$during the absorption of glycine and lysine whether or not the yeast was starved. The loss of $\mathrm{K}^{+}$presumably limited the extent to which the cells swelled. It may have been the result of electrical depolarization during the absorption of glycine with protons (Slayman \& Slayman, 1974; Seaston et al., 1976).

Size of the glycine pool. The evidence relating to the control of the uptake mechanisms is twofold. The influx of glycine into the unstarved yeast preparations decreased when the amount of glycine in the yeast increased. We interpret Fig. 2 as showing that the process affected is probably the general amino-acid permease, a proton symport system (Seaston et al., 1973; Seaston et al., 1976), which exhibits a $K_{\mathrm{m}}$ of about $60 \mu \mathrm{M}$ towards glycine (Eddy et al., $1970 a$ ). When the yeast contained about 0.8 to $0.9 \mu$ mol glycine $\mathrm{mg}^{-1}$ the relatively slow entry of glycine kept pace with its metabolism. The process so regulated may not involve the general amino-acid permease. It exhibits a relatively large $K_{\mathrm{m}}$ towards glycine and has not been characterized further.

The capacity of the starved yeast to absorb glycine compared with that of the unstarved yeast is interesting from two aspects. First, starvation seemingly both initiated glycine transport into the vacuole and increased the initial rate of glycine uptake. Kuznar et al. (1973) suggest that the derepression of permease activity in yeast during nitrogen starvation may involve the biosynthesis of new carrier molecules. Secondly, whereas a glycine content of about $0.9 \mu \mathrm{mol} \mathrm{mg}^{-1}$ appeared to stop the further rapid influx of glycine into the unstarved preparations, apparently by lowering the activity of the general amino-acid permease, prior starvation seemingly lifted the restriction on its activity. Several other examples of apparent feedback inhibition of permease activity have been described in the literature on yeast (Crabeel \& Grenson, 1970) and other micro-organisms (Hunter \& Segel, 1973), although the underlying mechanisms have not been established. Hunter \& Segel (1973) proposed that specific proteins might inhibit the permease, either by regulating its activity or promoting its degradation, both processes possibly being accelerated in the presence of the accumulated substrate.

The above concept of a regulatory process that is accessory to the working of the aminoacid pump is consistent with the present observations. In particular the regulatory mechanism limited the uptake of glycine into the unstarved yeast to about a $0.28 \mathrm{M}$ solution in the cellular water. This represented about a $0.32 \mathrm{M}$ solution in the cytoplasmic compartment. In contrast the starved yeast absorbed glycine rapidly when the glycine concentration in the cytosol was probably at least $0.45 \mathrm{M}$. The change brought about by starvation, together with the fact that the early but not the delayed addition of $0.2 \mathrm{M}-\mathrm{KCl}$ appeared to restore the regulatory mechanism in the starved yeast, indicates that either a rise in the tonicity of the cell or a rise in the glycine concentration in the cytosol was a necessary but not a sufficient condition to trigger the regulatory process.

\section{REFERENCES}

Boller, T., Dürr, M. \& Wiemken, A. (1975). Characterization of a specific transport system for arginine in isolated yeast vacuoles. European Journal of Biochemistry $54,8 \mathrm{I}-9 \mathrm{I}$.

Brown, C. M. \& Johnson, B. (1970). Influence of the concentration of glucose and galactose on the physiology of Saccharomyces cerevisiae in continuous culture. Journal of General Microbiology 64, $279-287$.

Cockburn, M., EARnshaw, P. \& Eddy, A. A. (1975). The stoicheiometry of the absorption of protons with phosphate and L-glutamate by yeasts of the genus Saccharomyces. Biochemical Journal 146, 705-712.

Crabeet, M. \& Grenson, M. (1970). Regulation of histidine uptake by specific feedback inhibition of two histidine permeases in Saccharomyces cerevisiae. European Journal of Biochemisty 14, 197-204.

Dürr, M., Boller, T. \& WIEMKEN, A. (1975). Polybase induced lysis of yeast spheroplasts. Archives of Microbiology ro5, 319-327. 
EDDY, A. A. \& NowACKI, J. A. (197I). Stoicheiometrical proton and potassium ion movements accompanying the absorption of amino acids by the yeast Saccharomyces carlsbergensis. Biochemical Journal 122, 70I-7II.

EdDY, A. A., INDGE, K. J., BACKEN, K. \& NowACKI, J. (1970a). Interactions between potassium ions and glycine transport in the yeast Saccharomyces carlsbergensis. Biochemical Journal x20, 845-852.

EDDY, A. A., BACKEN, K. \& WATSON, G. (1970b). The concentration of amino acids by yeast cells depleted of adenosine triphosphate. Biochemical Journal r20, 853-858.

Grenson, M., Hou, C. \& Crabeel, M. (1970). Multiplicity of the amino acid permeases in Saccharomyces cerevisiae. IV. Evidence for a general amino acid permease. Journal of Bacteriology 103, 770-777.

HuNTER, D. R. \& SEgel, I. H. (1973). Control of the general amino acid permease of Penicillium chrysogenum by transinhibition and turnover. Archives of Biochemistry and Biophysics 154, 387-399.

INDGE, K. J. (1968). Polyphosphates of the yeast cell vacuole. Journal of General Microbiology 5I, 447-455.

KOTYK, A., PONEC, M. \& ŔfHOVÁ, L. (1971). Uptake of amino acids by actidione-treated yeast cells. I. Specificity of carriers. Folia microbiologica 16, 432-444.

KuZNAR, J., SchWENCKe, J. \& MAgAÑA-SChWENCKE, N. (1973). Sarcosine and imino acid uptake in Saccharomyces chevalieri. Biochimica et biophysica acta 318, 273-280.

Matile, Ph., MoOR, H. \& Robnow, C. F. (1969). Yeast cytology. In The Yeasts, vol. I, pp. 219-302. Edited by A. H. Rose and J. S. Harrison. London: Academic Press.

PAtching, J. W. \& Rose, A. H. (1971). Cold osmotic shock in Saccharomyces cerevisiae. Journal of Bacteriology 108, 451-458.

SchlenK, F., DaINKo, J. L. \& Svirla, G. (1970). The accumulation and intracellular distribution of biological sulfonium compounds in yeast. Archives of Biochemistry and Biophysics 140, 228-236.

SCHWENCKE, J., FARtAs, G. \& ROJAS, M. (1971). The release of extracellular enzymes from yeast by 'osmotic shock'. European Journal of Biochemistry 21, 137-143.

Seaston, A., Inkson, C. \& EDDY, A. A. (1973). The absorption of protons with specific amino acids and carbohydrates by yeast. Biochemical Journal 134, 103I-1043.

SEAston, A., CARR, G. \& EDDY, A. A. (1976). The concentration of glycine by preparations of the yeast Saccharomyces carlsbergensis depleted of adenosine triphosphate. Effects of proton gradients and uncoupling agents. Biochemical Journal 154, 669-676.

Slayman, C. L. \& Slayman, C. W. (1974). Depolarization of the plasmamembrane of Neurospora during active transport of glucose: evidence for a proton-dependent cotransport system. Proceedings of the National Academy of Sciences of the United States of America 71, 1935-1939.

Svitla, G., DAINKo, J. L. \& SchlenK, F. (1969). Ultraviolet micrography of penetration of exogenous cytochrome $c$ into the yeast cell. Journal of Bacteriology 100, 498-504.

WIEMKEN, A. \& DÜRR, M. (1974). Characterization of amino acid pools in the vacuolar compartment of Saccharomyces cerevisiae. Archives of Microbiology 101, 45-57.

WIEMKEN, A. \& NURSE, P. (1973). Isolation and characterization of the amino acid pools located within the cytoplasm and vacuoles of Candida utilis. Planta 109, 293-306.

YphaNTIS, D. A., DAINKo, J. L. \& SCHLENK, F. (I967). Effect of some proteins on the yeast cell membrane. Journal of Bacteriology 94, 1509-1515. 